\title{
THE PROFILE OF PRIMARY ENGLISH TEACHERS IN INDONESIA
}

\author{
B. Yuniar Diyanti, Lusi Nurhayati, and Nury Supriyanti \\ Universitas Negeri Yogyakarta \\ Email: yuniar_diyanti@uny.ac.id
}

\begin{abstract}
After the implementation of the 2013 national curriculum which excludes English from the primary school, many primary schools in Indonesia keep offering English to the students despite the uncertainty of the status of English for the primary school. However, the state of the practice of English currently in primary schools is barely unknown. This study is an attempt to portray the teachers that strive to teach English in the primary schools in one of the regencies that are still implementing English education. This survey study involved 44 randomly selected Primary English teachers (PETs) in the regency. The research instrument was a set of online (google format) and offline questionnaires. Results show that the majority of the teachers have English teaching qualification, however only very few ever attended pre-service or in-service training for teachers of young learners. The teachers also deal with employment uncertainty as primary English has no formal legal government policy. The findings bring about the issue of gaps and opportunities for professional developments of PETs and inequality in professional supports for PETs.
\end{abstract}

Keywords: English for young learners (EYL), primary English, primary English teacher $(\mathrm{PET})$

\section{PROFIL GURU BAHASA INGGRIS SEKOLAH DASAR DI INDONESIA}

\begin{abstract}
Abstrak
Setelah penerapan Kurikulum 2013 yang tidak mengikutsertakan bahasa Inggris sebagai mata pelajaran pilihan muatan lokal (mulok) dalam kurikulum Sekolah Dasar (SD), banyak SD di Indonesia yang tetap menyelenggarakan pembelajaran bahasa Inggris dalam suasana ketidakpastian. Tidak diketahui kondisi pembelajaran bahasa Inggris di SD saat ini. Penelitian ini berusaha untuk menggambarkan guru-guru bahasa Inggris yang berjuang untuk tetap mengajarkannya di salah satu kabupaten di Indonesia yang tetap mengizinkan pembelajaran bahasa Inggris di SD. Penelitian survei ini melibatkan 44 guru bahasa Inggris SD yang dipilih secara acak dan instrumen yang digunakan adalah seperangkat kuesioner daring (googleform) dan luring (cetak). Hasil penelitian menunjukkan bahwa mayoritas guru memiliki latar beakang pendidikan bahasa Inggris, namun hanya sedikit sekali yang pernah mengikuti pelatihan pengajaran bahasa Inggris bagi anak-anak. Guru-guru tersebut juga menghadapi ketidakjelasan status kepegawaian yang disebabkan tidak adanya aturan pemerintah yang jelas tentang
\end{abstract}


bahasa Inggris di SD. Temuan penelitian mengangkat isu tentang kesenjangan pada pengembangan professional guru bahasa Inggris SD dan ketimpangan dalam dukungan profesional bagi guru-guru tersebut.

Kata Kunci: bahasa Inggris bagi anak-anak (EYL), bahasa Inggris di SD, dan guru bahasa Inggris SD

\section{INTRODUCTION}

The teaching of English to students of Primary School age has become a common practice globally for the past 40 years (Rixon, 2013) as evidently seen in the increasing number of polities which include English learning policy in their primary schools, (Enever \& Moon, 2009; Kaplan, Baldauf, \& Kamwangamalu, 2012). This policy is driven frequently by the economy (Enever \& Moon, 2009) and political interests (Kirkpatrick, 2012) believing that more citizens to speak English for international interaction the more beneficial it is for the countries' economy and politics. Although there is very little evidence showing the relationship between English mastery and economic growth there are still high demands for early introduction of English to primary school students which mostly come from parents, (Hayes, 2016).

Following the global mainstream, Indonesian EYL practice dated back in the 1980s in which a study reporting parents' strong belief on the needs of children to study English and the unsatisfactory results of the secondary schoolers' English proficiency (Lestari, 2003) led to thoughts to bring English to primary schools. English was introduced to primary school curriculum through Presidential Decree Number 28 Year 1990, (Kirkpatrick \& Liddicoat, 2017) which later elevated to become local content subject by the issuing of the Decree of Ministry of Education and Culture Number 060 Year 1993, (Alwasilah, 2013; Hawanti, 2014; Iskandar, 2015; Zein, 2017). The policy implied that schools might choose to teach English to grades 4, 5, and 6 or chose to teach other subjects such as arts, dance, music, or sports more suited to their socio-economic and geographical situation and needs in which the schools are located.

As there was intense pressure from parents who did not want their kids to be left behind in learning English, most primary schools decided to have English (Zein, 2014 \& 2015; Lestari 2003; Hawanti, 2014) as their local content subject. The policy led to a dilemma as it resulted in primary schools rushing to offer English to pupils without considering whether or not they were ready with it. There were reports of poor classroom performance by underqualified teachers (Zein, 2011, 2014 \& 2015; Lestari, 2003; Hawanti, 2014). The poor classroom practices might also root from the non- relevant teachers' qualification as a study conducted by Alwasilah (2013) among the primary English teachers, revealed that about $58 \%$ of primary English teachers in the provinces of Jakarta, West Java, and Banten had 
neither English background nor a proper TEYL training. He further reported that the teachers' teaching was 'bookish' as they relied so much on textbooks and students worksheet since developing own materials was not an easy task.

Zein (2015) points that teachers lacked spelling accuracy, had poor pronunciation (Suyanto and Chodidjah, 2002) and fluency (Chodidjah, 2007), and dealt with difficulties in terms of classroom management (Sikki, Rahman, Hamra, \& Noni, 2013). Further studies reported that the poor quality of primary English was not rooted only from teachers' poor performance but also from budget shortage leading to lack of teaching resources (Hawanti, 2014) and facilities to support learning (Faridi, 2010; Lestari, 2003; Sulistiyo, et.al., 2019). It shows that the policy was not thoroughly prepared which led to a somewhat hasty decision when implemented.

After experiencing a bloom for about 20 years, in 2013, however, English in primary schools became an optional or elective lesson (Lestariyana \& Widodo, 2018).

There were too many problems surrounding the practice of English in primary schools that educators and practitioners demanded an overhaul of the program. The government also referred to what so-called "falling standards in Bahasa Indonesia" (www. theguardian.com, 2012) as one of the retraction factors in which Bahasa Indonesia average scores reached a low nationally in the national exams (UN). The Ministry of Education of the Indonesian Republic stated that Bahasa
Indonesia needed to be given more portion in schools for not only it is the national language but also it is the national identity (detikNews, 2013). The new regulation applied to all public schools nationally but left room for private schools to maintain the program autonomously.

Of all the five regencies in the Yogyakarta Special Territory, only one Regency is allowing schools to run the English program both as a school subject and an extracurricular program. However, it is practically unknown how many and which schools continue providing an English program for the pupils. It is unclear how they implement it and the kind of support the schools provide teachers to maintain the program is unknown either. From 1993 to 2013 the English teachers workgroup (KKG) became a legitimately acknowledged teachers' association body for primary English teachers to share thoughts and other types of information. The KKG also served as an information center for universities and researchers to obtain information regarding primary English. However, since the ending of primary English, the KKG is dismissed which also resulted in difficulty in acquiring information on teachers' current state and how teachers perceived their current teaching situation. Therefore, this article aimed at reporting a survey to describe the profile of Indonesian primary English teachers in this Regency, framed by two research questions: (1) What is the demographic profile of the primary English teachers? and (2) How do Primary English teachers perceive their current employment status? 
A study by Zein (2017) found that the teachers teaching English in Indonesian Elementary Schools (ES) fall into two categories, Specialists and Generalists. There are 103.667 specialist PETs in Indonesia serving 147.536 Elementary Schools, according to the Indonesian Ministry of Education and Culture (Kemdikbud, 2016). The gaps for English teachers' insufficiency are met by the generalists who are mostly homeroom teachers. Generalist teachers teach other subjects besides English and teach English only to students in their class, (Zein, 2017) and may sometimes consider other subjects more important than English as English is not their focus (Hawanti, 2014). These teachers also generally have low English proficiency, (Zein, 2017) and often struggle with designing English learning tasks and activities, learning materials, and appropriate assessment (Hawanti, 2014; Sulistiyo, Haryanto, Widodo, \& Elyas, 2019). Specialist teachers, on the other hand, generally have more various English proficiency and teach English to students from various grades, (Zein, 2017).

Indonesian PETs may also be classified based on their educational background. Teachers in the Indonesian educational system hold a degree from a teacher education college or university. As a homeroom teacher, generalist PETs commonly have a degree from Primary School Teacher Education (PGSD [Pendidikan Guru Sekolah Dasar]) which provides them the knowledge and skills of teaching young learners, (Zein, 2017; Zein, 2014). Their experience with English is usually obtained from a one- semester subject of English for University Students (MKU Bahasa Inggris) during their undergraduate study, (Zein, 2014) which is inadequate to enable them to teach English. The Specialist teachers generally hold a degree in English Language Education or other languagerelated majors with some barely have the knowledge of teaching young learners while some others may take English for Young Learners subjects if their educational institution offers the EYL courses, (Zein, 2017; Zein, 2014).

Zein (2016) revealed that PETs need training in three areas; first, improving language proficiency which includes pronunciation and effective codeswitching between English, and children's L1. In some observed classes, teachers commonly switch between two or three languages i.e. English, Bahasa Indonesia, and the children's mother tongue. Teachers feel that they need a better technique to implement code switching effectively for teaching learning. Secondly, PETs need pedagogical improvement including lesson planning, material selection and adaptation (Zein, 2016; Noni, 2016), classroom management, error correction, and feedback provision. A study by Hawanti (2014) found that when teachers encounter the situation in which a national curriculum for primary English is unavailable, teachers turn to available textbooks in conducting their English teaching as textbooks provide them with all the necessary materials, tasks, and exercises to facilitate students' learning. Third, PETs need to learn basic knowledge of EYL which includes understanding young learners and 
pedagogy of young learners.

In terms of teachers' professional development, it is a pivotal point that PETs receive a personal and professional development trainings to develop their pedagogical skills and competence, enhance theoretical and practical knowledge related to teaching the young learners, manage and regulate learningteaching, and develop English skills, (Brewster, Ellis, \& Girard, 2002; Uztosun, 2018). However, Zein (2015) found that not all PETs have opportunities to attend professional development workshops or training. Some teachers had been invited to government-funded training several times while others had never had any. PETs also reported that the training contents sometimes did not match with the participants' needs and most training were unstructured and often condensed from several days into one-day training. PETs also reported that they do not have the necessary professional development support either from the central or local government, (Sulistiyo, et.al., 2019).

This study is an attempt to portray the teachers that strive to teach English in Primary Schools in one of the Regencies still implementing English in Primary Schools in Indonesia.

\section{METHODS}

This small scale survey used a questionnaire as the main instrument. The questionnaire which consisted of close-ended and open-ended questions (appendix 1) was divided into four sections namely general information (such as gender, education background, name of school, teaching experience, TEYL training experience, English proficiency, and employment status), TEYL pedagogy (skills to teach, activities, media, resources, assessment), challenges and hopes (note: the findings concerning TEYL pedagogy is given in another article, hence they are excluded from this report). It was made by using google form, validated by 2 TEYL experts (teacher educators) and 2 primary English teachers, and distributed through social media (WhatsApp and Facebook). This method was chosen due to time effectiveness.

This study was done in Sleman Regency of Yogyakarta Special Province, Indonesia. Since not all elementary schools in the regency provide English, therefore three steps i.e. identifying, selecting, and finalization were done to get the data. In the initial step, the researcher consulted with the local education office (UPT Dinas Pendidikan) to obtain data of the schools providing English. The office gave a register informing that in 17 subdistricts of the regency there were 326 schools (226 public and 100 private schools) that provide EYL service, however, these numbers did not represent the number of teachers as some teachers work in more than one schools. In the second stage, the listed schools were categorized and selected by considering the proportion of schools in each subdistrict and taking into account factors such as status (state/ private), location (city/rural), and access (availability of mobile phone numbers). International schools were excluded from the list. Finally, 77 schools were selected as samples. Then, the teachers, whose phone numbers were listed in the UPT's register, were contacted to be asked if 
they could participate in the online survey. However, not all of the numbers can be reached and not all of those who could be contacted were able to participate; hence until the deadline of data collection only 44 participated.

The quantitative data obtained in the study were analyzed using descriptive statistics while the qualitative data were analyzed following the qualitative data analysis proposed by Miles, Huberman, \& Saldana (2014) which included data condensation, data display, and conclusion drawing.

\section{RESULT AND DISCUSSIONS Result}

The profiles of the primary English teachers fall into four categories: demographic information, beliefs, challenges, and hopes.

\section{Demographic Information}

The demographics of the respondents consisting of nationality, gender, age, educational background, TEYL training background, and employment status are presented in table 1 . In total, there were 44 teachers from state primary schools $(\mathrm{n}=15)$ and private primary schools $(n=29)$ in Sleman regency responding to the questionnaire.

As table 1 illustrates, the majority of the respondents from both state and public schools were female $(86 \%)$ and both types of schools employed young teachers (94\%) ranging from 20-30 (64\%) and $30-40(30 \%)$ years of age.

Overall, most of the respondents (84\%) have got English education background i.e. bachelor degree (73\%) and postgraduate degree (11\%); while 7
$\%$ of them hold a bachelor degree and a postgraduate degree in non-English education. From the data, it was learned that some state primary schools employed graduates of senior high schools $(2 \%)$ and Diploma in English program (7\%), hence, in terms of educational background, comparing to the state schools, private schools recruit "better" as they employ teachers graduating from undergraduate level (100\%) although some of them do not have English education background.

The data also revealed that the teachers have different TEYL training experiences and that not all teachers in both private and state schools have adequate TEYL training background. As shown in the data, only $43 \%$ of the responding teachers have ever had formal training while the rest have never had any. Moreover, the types of training they attended were varied either extra classes or subjects they took in their undergraduate classes, workshops conducted by universities, teachers' associations, NGOs, and publishers. The training duration ranged from one day workshop to one semester (6 months) training.

Regarding EYL professional development (PD), the responding teachers shared different experiences. Reporting about supports from schools, $61 \%$ expressed that the schools had given the full support for PD by sending them to workshops or other training conducted by a local or international institution (such as Cambridge), while16 \% are half supported by schools. However, $23 \%$ of them reported they received none that they had to independently look for one themselves. 
In this study, the status of the teachers was divided into three categories: fulltime generalists, fulltime specialists, and parttime specialists. It is clear from the data that nearly half of the respondents' status was part-time specialists (41\%), while the rest belong to fulltime generalists (36\%) and fulltime specialists (23\%). Half of the responding teachers reported that each of them was the only English in their schools, while another half said that they collaborate with other English teachers. Meanwhile, as much as $46 \%$ part-time specialist teachers said that they teach English in more than one school. Regarding the teaching experience, $60 \%$ of the teachers have got at least 1-5 years of teaching experience while the rest, 40\%, have been English teachers for 5 to 10 years or more.

When asked to describe their skills in English, $21 \%$ of teachers claim they have good English proficiency and 68\% claimed to have sufficient English proficiency, and the rest admitted that they think their English is not good enough. Those who claimed to have good and sufficient English proficiency said their TOEFL scores range from 500 to 600 while the rest only scored below 450 .

Table 1. The Demographics of EYL Teachers in Sleman Regency

\begin{tabular}{|c|c|c|c|}
\hline & $\begin{array}{c}\text { State } \\
\text { School Teachers } \\
(\mathrm{n}=15)\end{array}$ & $\begin{array}{c}\text { Private School } \\
\text { Teachers }(n=29)\end{array}$ & $\begin{array}{c}\text { Total } \\
(\mathrm{n}=44)\end{array}$ \\
\hline \multicolumn{4}{|l|}{ Nationality } \\
\hline Indonesia & $100 \%$ & $100 \%$ & $100 \%$ \\
\hline \multicolumn{4}{|l|}{ Gender } \\
\hline female & $80 \%$ & $90 \%$ & $86 \%$ \\
\hline male & $20 \%$ & $10 \%$ & $14 \%$ \\
\hline \multicolumn{4}{|l|}{ Age } \\
\hline $20-30$ & $80 \%$ & $55 \%$ & $64 \%$ \\
\hline $30-40$ & $13 \%$ & $38 \%$ & $30 \%$ \\
\hline $40-50$ & - & $7 \%$ & $7 \%$ \\
\hline$>50$ & $7 \%$ & - & $2 \%$ \\
\hline \multicolumn{4}{|l|}{ Education Background } \\
\hline Senior High School & $7 \%$ & - & $2 \%$ \\
\hline Diploma in English & $20 \%$ & - & $7 \%$ \\
\hline \multicolumn{4}{|l|}{ Undergraduate/Bachelor } \\
\hline English Education Dept. & $53 \%$ & $83 \%$ & $73 \%$ \\
\hline Non English Education Dept. & $13 \%$ & $10 \%$ & $2 \%$ \\
\hline \multicolumn{4}{|l|}{ Postgraduate } \\
\hline English Education Dept. & - & $3 \%$ & $11 \%$ \\
\hline Non-English Education Dept. & $7 \%$ & $3 \%$ & $5 \%$ \\
\hline \multicolumn{4}{|l|}{ Employment status } \\
\hline Fulltime generalist & $27 \%$ & $41 \%$ & $36 \%$ \\
\hline Fulltime specialist & $20 \%$ & $24 \%$ & $23 \%$ \\
\hline Part-time specialist & $53 \%$ & $34 \%$ & $41 \%$ \\
\hline
\end{tabular}




\begin{tabular}{lccc}
\hline & $\begin{array}{c}\text { State } \\
\text { School Teachers } \\
(\mathrm{n}=15)\end{array}$ & $\begin{array}{c}\text { Private School } \\
\text { Teachers }(\mathrm{n}=29)\end{array}$ & $\begin{array}{c}\text { Total } \\
(\mathrm{n}=44)\end{array}$ \\
\hline $\begin{array}{l}\text { TEYL Training Participation } \\
\quad \text { Yes }\end{array}$ & $47 \%$ & $41 \%$ & $43 \%$ \\
$\quad$ No & $53 \%$ & $59 \%$ & $57 \%$ \\
Teaching experience & & & \\
$\quad$ 1-5 years & $73 \%$ & $53 \%$ & $60 \%$ \\
$\quad$ 5-10 years & - & $31 \%$ & $20 \%$ \\
$\quad$ More than 10 years & $27 \%$ & $17 \%$ & $20 \%$ \\
English Proficiency & & & \\
Good & $23 \%$ & $24 \%$ & $21 \%$ \\
Sufficient & $69 \%$ & $68 \%$ & $68 \%$ \\
Not enough & $7 \%$ & $8 \%$ & $11 \%$ \\
\hline
\end{tabular}

\section{Teachers' Belief about Learning English in Primary Level}

Although the teachers' beliefs about English are varied, overall these are positive and supportive and all of them perceived English as a very important subject to study in Indonesian elementary schools. These teachers (82\%) believed that learning English in primary schools is beneficial for students because they would be more prepared when studying English in Junior High School; meanwhile, 64\% of them said that the early English learning help to motivate students to learn English more and create in them positive attitude toward learning a foreign language. As much as $55 \%$ of the teachers say that English is an important foreign language that should be taught in Elementary school level because of its status as a significant international language, thus the students in the future will be required to be able to communicate in the language for study or work purposes. About $36 \%$ of the respondents believed that the sooner the children start learning English and the longer the duration, the more proficient they will be. Finally, 34\% assumed English should be a subject in the primary school because kids love it, and another 34\% asserted that children have the right to learn a foreign language at primary level.

\section{Challenges}

Apart from the unavailability of supports from schools for some teachers, the Primary English teachers also dealt with some difficulties related to a large number of students, gaps in students' abilities, lack of parent supports, limited classroom and school facilities, limited financial support, and the nonavailable national government support. The most prominent problem, according to teachers, was government policy related to the position or the status of English in primary English which is unclear ( $77 \%$ ). The teachers claimed that the national government neglected them in terms of professional support, availability of standardized guidelines for primary English, and formal government regulation related to primary English. The absence of formal government regulation related to primary English and a national curriculum guideline were burdening too 
as it affected teachers' socioeconomic welfare as well as career development (48 $\%$ ). Further, $43 \%$ of teachers also reported that the absence of regulation presupposed weak supervision towards English teaching and learning in the primary schools.

The teachers claimed that English is not considered as an important subject in elementary school, it is not tested in the national examination (UN), therefore it is alloted very limited time in school (54\%). Since English is not tested in UN, $25 \%$ of teachers also reported that it leads to the lack of parents' involvement in supporting the children's learning in the forms of neglected homework or takehome tasks and low attendance in English extracurricular activities.

The fourth problem is related to limited classroom facilities and other supporting media (46\%). Next, the big gaps in students' abilities (48\%) and a large number of students (27\%) were also reported as problems related to students and class management. Further, a small number of teachers $(18 \%)$ reported that they had difficulties with students who showed very little interest in learning English.

Regarding their teaching practice, $48 \%$ of teachers who write their own materials either regularly or occasionally admitted that they have difficulties in providing the appropriate teaching learning materials and media due to the limitation of time and financial supports from schools. Moreover, $31 \%$ of the teachers claimed that their lack of training in the techniques of teaching young learners contributed to their performance shortcoming in class.

\section{Teachers' Hopes}

Amidst the problems mentioned above, the teachers have several expectations related to the sustainability of their careers as English teachers. Their expectations are grouped into three areas related to their professional development, National regulation and curriculum, and financial support. The teachers expected to be given more workshops and training for professional development. They wish to be admitted as "real" English teachers and have the same professional and employment rights as secondary English teachers. Moreover, they also expect to have teachers workgroup (KKG) revived so they have a sharing forum. They believe that everyone in the country should shift to the paradigm that English is important for the younger generation to be able to compete internationally. They hope that the government will eventually bring back primary English considering its importance in the world. Besides, they concerned about the absence of national curriculum and policy to regulate and standardize the implementation of primary English; in other words, they wish these to exist. The teachers expected the government to provide easy access to materials (textbooks) and other supporting media. Moreover, they expected that ample time and opportunities be allocated to ensure the success of English language learning in primary schools.

\section{Discussion}

This study confirms that more than half of the teachers belong to the age group of 20-30 years old with a variety of teaching experiences ranging from 1 to 5 
years. This group of teachers may be classified as junior teachers (novice) who are most in need of guidance from senior teachers or other supporting systems. Being in a circle of the same profession group is beneficial to support teachers' professional development. Moreover, exchanging ideas with colleagues, mentors or trainers, and teachers from other schools about professional difficulties support teaching improvement (Grangeat \& Gray, 2007). These young teachers could faster transform themselves to be more professional teachers by learning from other teachers' experiences. However, some of them hardly ever get these kinds of supports, instead, some of them have to be a 'single fighter' at schools. They do most of the job, starting from making the syllabus, planning and organizing the activities, selecting resources, and doing the evaluation.

This study shows that there is a gap in professional supports among EYL teachers in the regency. Some teachers teaching in strong financial private schools have better opportunities for collegial assistance since the number of English teachers in these schools is sufficient to allow them to have their own circle of teachers group. However, as most schools only have one or two English teachers, collegial assisstance is hard to do. The dismissal of KKG makes things worse as it leaves teachers with very little opportunity to share or cooperate with other teachers to improve themselves professionally.

It could be argued PETs need to have a good command of English as well as pedagogical knowledge and skills of
TEYL. The absence of formal rules concerning PETs minimum competences influences the teachers' recruitment practices at schools. The data showed that the number of teachers with sufficient background of TEYL training and education was very limited although most teachers show sufficient English proficiency. Not all schools are adamant about how the English classes should be implemented. This can be seen from the low support for teachers' professional development. Hayes (2014) argues that the teaching of English for young learners are supposed to be conducted by teachers who are sufficiently trained in primary English language teaching method and teachers with a sufficient level of English. Untrained teachers may view class situations such as a large number of students and their mixed ability as a challenge. Brewster, et.al. (2003) have suggested that with careful planning, teachers can accommodate their large class with a more suitable seating arrangement and various types of activities that would challenge the more able pupils as well as support the less able.

Teachers with insufficient training may also view low parental support as a thread. Despite its contradictory notion with the commonly acknowledged parental enthusiasm as being one of the most influential drives of EYL practice (Carmel, 2019) most teachers in this study are faced with this dilemma. It can be stated that there is a gap in teachersparents communication. Inclusion of parents-teacher (school) cooperation subject in teacher training is important for teachers working in primary schools, 
(Lehmann, 2018). Some of the teachers who do not have a degree in English education or never attend any TEYL training need to be empowered through in-service teacher training to acquire the necessary competences. It is financially hard for junior teachers to continue seeking training autonomously, therefore schools can turn to universities or other teacher training institutes to facilitate teachers for in-service training on TEYL to improve teaching quality.

The study also revealed gaps related to continuing professional development for the teachers. Sulistiyo, et.al. (2019) recommended that both central and local government provide an EYL curriculum framework that teachers can use to guide them in designing the syllabus and provide the learning materials. PETs, thus, will need to be empowered to be able to design their syllabus and materials. The absence of the regulation and national primary English curriculum, however, has made it difficult for PETs to not only acquire their rights as for continuing professional development training but also their full employment status. To be a full-time primary English teacher, they need to take a PPG program (Teachers' Professional Training Program). However, the PPG program cannot accommodate primary English teachers as the government does not acknowledge English in primary schools. These teachers may have two options; relocating to secondary education or becoming primary homeroom teachers which also means they have to teach other subjects and take a degree in Elementary School Education. A change of primary English status will ensure better opportunities for PETs to acquire the necessary professional development training that they need, (Sulistiyo, et.al., 2019).

\section{CONCLUSION}

Primary English teachers have to deal with several challenges mainly prompted by the absence of the government standard regulation, one of the main effects of which is their employment status and limited opportunity to acquire a professional development training. The findings in this survey cannot be used to generalize the current condition of all Indonesian primary English teachers as the study was conducted in only one Regency in Indonesia with a limited number of respondent-teachers. The study, however, fills a gap in answering the questions on the current state of primary English teachers, their needs, and expectations as well as how they perceive their current status as primary English teachers in the absence of formal regulation.

\section{ACKNOWLEDMENTS}

The writers wish to thank the Faculty of Languages and Arts, Yogyakarta State University and Sleman Regency Education Office for supporting the study.

\section{REFERENCES}

Alwasilah, A. C. (2013). Policy on Foreign Language Education in Indonesia. International Journal of Education, 7 (1), 1-19, DOI: https:// doi.org/10.17509/ije.v7i1.5302

Brewster, J., Ellis, G., \& Girard, D. (2002). The Primary English Teacher's 
Guide. London: Pearson Education Limited.

Carmel, R. 2019. Parents' Discourse on English for Young Learners. Language Teaching Research 1-19. DOI: $10.1177 / 1362168819877080$.

Chodidjah, I., 2007. Teacher Training For Low Proficiency Level Primary English Language Teachers: How it is Working in Indonesia. In: British Council, ed. Primary innovations: A collection of papers. Hanoi: British Council, 87-94.

Enever, J. \& Moon, J. (2009). New Global Contexts for Teaching Primary ELT: Change and Challenge. In J. Enever, J. Moon, \& U. Raman. (Eds.). Young Learner English Language Policy and implementation: International Perspectives. $\quad$ Reading: garnet Publishing Ltd.

Faridi, A. (2010). The Development of Context-Based English Learning Resources for Elementary Schools in Central Java. Excellence in Higher Education, 1(1\&2), 23-30.

Grangeat, M. \& Gray, P. (2007). Factors Influencing Teachers' Professional Competence Development. Journal of Vocational Education and Training, 59(4), December 2007, pp. 485-501. DOI: $10.1080 / 13636820701650943$.

Hawanti, S. (2014). Implementing Indonesia's English Language Teaching Policy in Primary Schools: The Role of Teachers' Knowledge and Beliefs, International Journal of Pedagogies and Learning, 9(2), 162170.

DOI:

10.1080/18334105.2014.11082029.

Hayes, D. (2014). Factors Influencing Success in Teaching English in State
Primary Schools. www.britishcouncil. org.

Hayes, D. (2016). Fallacies Affecting Policy And Practice in the Teaching of English As A Foreign Language in State Primary Schools in Asia. Asia Pacific Journal of Education http://dx.doi.org/10.1080/021887 91.2016.1240660.

Iskandar. (2015). Putting English As a Local Content Subject in Primary Schools: Teachers' Belief and Its Impact on Their Teaching Delivery. 62 $2^{\text {nd }}$ Teflin proceeding, Book 2, pp. 758767. (Online) https://www. $\mathrm{res}$ e a r c h g a $\mathrm{te}$. n e t / publication/319016760_Putting_ English_as_a_Local_Content_ Subject_in_Primary_Schools_ Teachers\%27_Belief_and_Its_ Impact_on_their_Teaching_ Delivery.

Kaplan, R. B., Baldauf, R. B., \& Kamwangamalu, N. M. (2012). Why Educational Language Plans Sometimes Fail. In R. B. Baldauf, R. B. Kaplan, N. M. Kamwangamalu, \& P. Bryant (Eds). Language Planning in Primary Schools in Asia. New York: Routledge.

Kementerian Pendidikan dan Kebudayaan (Kemdikbud). Pusat Data dan Statistik Pendidikan dan Kebudayaan. (2016). Statistik Sekolah Dasar (SD) 2015/2016. Jakarta: Setjen, Kemdikbud.

Kirkpatrick, A. (2012). English in ASEAN: Implications for Regional Multilingualism. Journal of Multilingual and Multicultural Development, 33(4), 331-344. https://doi.org/10.1080/01 434632.2012.661433. 
Kirkpatrick, A., \& Liddicoat, A. J. (2017). Language Education Policy and Practice In East and Southeast Asia. Language Teaching, 50(02), 155-188. doi:10.1017/s0261444817000027.

Lehmann, J. (2018). Parental Involvement: An Issue for Swiss Primary School Teacher Education. Journal of Education for Teaching, $\mathrm{D}$ $\mathrm{O} \quad \mathrm{I}$ 10.1080/02607476.2018.1465626.

Lestari, L. A. (2003). Should English be a Compulsory Subject in Primary Schools? BAHASA DAN SENI, 31(2), 197-213. http://sastra.um.ac.id/ wp-content/uploads/2009/10/ Should-English-be-A-CompulsorySubject-in-Primary-Schools-LiesAmin-Lestari.pdf.

Lestariyana, R. P. D., \& Widodo, H. P. (2018). Engaging Young Learners Of English With Digital Stories: Learning to Mean. Indonesian Journal of Applied Linguistics, 8(2), 489-495. DOI: https://doi.org/10.17509/ ijal.v8i2.13314

Lotbiniere, M. d. (2012. Indonesia to End Teaching of English in Primary Schools. The Guardian. Retrieved from https://www.theguardian. com/education/2012/nov/13/eltdiary-november-indonesia-english.

Mendikbud: Bahasa Inggris Tidak Wajib, Bukan Dihapus (Minister of Education and Culture: English Is Not Compulsory, Not Deleted) (2013, December 11), detiknews. Retrieved from https://news.detik.com/ berita/d-2439452/mendikbudbahasa-inggris-tidak-wajib-bukandihapus.
Miles, M.B., Huberman, A.M. \& Saldana, J. 2014. Qualitative data analysis: A method Source Book. Thousand Oaks: Sage.

Noni, N. (2016). Primary School Teachers Perceptions of and Practices in the Selection and Development of English Learning Materials. LITERA, Jurnal Penelitian Bahasa, Sastra, dan Pengajarannya), 15(2), 227-238. DOI: https://doi.org/10.21831/1tr. v15i2.11825.

Rixon, S. (2013). British Council Survey of Policy and Practice in Primary English Language Teaching Worldwide. London: British Council available online at www.britishcouncil.org.

Sikki, A. A., Rahman, A., Hamra, A. \& Noni, N. (2013). The Competence of Primary School English Teachers in Indonesia. Journal of Education and Practice, 4(11) 2013. (Online) www.iiste.org.

Sulistiyo, U., Haryanto, E., Widodo, H. P., \& Elyas, T. (2019). The Portrait of Primary School English in Indonesia:Policy Recommendations. Education 3-13. https://doi.org/10.1 080/03004279.2019.1680721.

Sutrisno, A. (2013). Teaching English to Young Learners: Beneficial or Deprimental? How Do We Go About it? https://www.kompasiana.com/

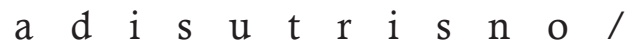
$552 \mathrm{fdbb} 86 \mathrm{ea} 8343 \mathrm{~d} 548 \mathrm{~b} 4584 /$ accessed on August 5, 2019.

Suyanto, K.E. and Chodidjah, I. (2002). The Teaching of English in Elementary Schools: The Policy, Implementation, and Future Direction. Paper presented 
at the 50th TEFLIN International Conference, Surabaya, 29-31 October.

Uztosun, M. S. (2018). Professional Competences to Teach English at Primary Schools in Turkey: A Delphi Study. European Journal of Teacher Education, DOI: 10.1080/02619768.2018.1472569.

Zein, M. S. (2011). One Size Does Not Fit All: Unravelling The Needs of English Teachers in Primary Schools in Indonesia. International Conference on Languages, Literature and Linguistics IPEDR vol.26. Singapore: IACSIT Press.

Zein, S. (2014). Pre-Service Education for Primary School English Teachers in Indonesia: Policy Implications. Asia Pacific Journal of Education, DOI:
10.1080/02188791.2014.961899. Zein, S. (2015). Factors Affecting the Professional Development of Elementary English Teachers. Professional Development in Education http://dx.doi.org/10.1080/19415257.20 15.1005243 .

Zein, M. S. (2016). Professional Development Needs of Primary EFL Teachers: Perspectives of Teachers and Teacher Educators. Professional Development in Education,

$\mathrm{D}$

$\mathrm{O}$ I

10.1080/19415257.2016.1156013. Zein, M. S. (2017). Elementary English Education in Indonesia: Policy developments,

current practices, and future prospects. English Today 129, Vol. 33, No. 1 (March 2017). doi:10.1017/ S0266078416000407.

Appendix 1. Blueprint of the questionnaire

\begin{tabular}{ll}
\hline \multicolumn{1}{c}{ Theme } & \multicolumn{1}{c}{ Item } \\
\hline Teachers' General information & 1. Nationality \\
2. Sex & 3. Age \\
4. Background education & 5. Teaching experience \\
6. Employment Status & 7. Subjects to teach beside English \\
8. Teaching hours per week & 9. Other schools to teach (primary/ secondary schools/others) \\
10. English proficiency & 11. English proficiency test ever taken and the score obtained \\
12. TEYL training ever taken (yes/no) & 13. Name of training, institution, training duration \\
14. Facilitation from school to take training (yes/no) & 15. Government-based PD training (yes/no)
\end{tabular}




\begin{tabular}{ll}
\hline \multicolumn{1}{c}{ Theme } & \multicolumn{1}{c}{ Item } \\
\hline Pedagogical Information & 1. Number of students in class \\
& 2. Number of English teachers in school \\
& 3. Status of English in school \\
& 4. How to get learning materials (textbooks/coursebooks) \\
& 5. Curriculum, syllabus, lesson plan (available/not/own design) \\
& 6. Media (available/not/own design) \\
& 7. Teachers workgroup (available/not) \\
1. Why English is offered in schools \\
Beliefs & 2. Importance of English for primary schoolers \\
& 3. Benefits of learning English for primary schoolers \\
Challenges & 1. Challenges (yes/no) and kinds \\
Hopes & 1. Government (national and local) \\
& 2. Parents \\
& 3. Parental supports \\
4. Government-based professional development & 5. Formal and structured TEYL training \\
\hline
\end{tabular}

